\title{
The formal adaptation of toponyms in Romanian translations from German between 1780 and $1830^{\dagger}$
}

\author{
Ana-Maria Gînsac, Mădălina Ungureanu* \\ Department of Interdisciplinary Research in Social Sciences and Humanities, "Alexandru Ioan Cuza” University, Str. Lascăr \\ Catargi 54, 700107 Iași, Romania
}

\section{Article info}

History:

Received February 2, 2018

Accepted February 13, 2018

Published April 27, 2018

Key words:

language contact

onomasiology

toponymy

translation

secular literature

\begin{abstract}
Although the translation of foreign proper names into Romanian before its modern stage is insufficiently explored, it is known that the process is characterized (as the whole Romanian writing of the time) by the lack of generally valid norms. The process was influenced by various factors, including: the existence of different alphabets, orthographic and phonetic systems; the influence of the source-text vs. the existence of traditional pronunciation and writing patterns; the translation of a proper name from various languages (French, German, Italian, etc.); the diversity of proper names; the translator's personality (linguistic knowledge, cultural formation). Starting from the translation strategies adopted by translators, our aim is to analyse the way in which the toponyms from three historical texts translated into Romanian from German in pre-modern stage (1780-1830) were adapted to the formal system of Romanian.
\end{abstract}

\section{Introduction}

Considered the "modern stage" in the history of literary Romanian (Gheție, 1982, p. 65; Munteanu \& T,âra, 1983, p. 169, 176), also referred to as the "pre-modern stage" (Piru, 1970, p. 5, referring back to the transition period from the old to the modern literature), the period between 1780-1830/40 represents the beginning of the modernization of Romanian through the translation of texts pertaining to various fields of the written culture (religion, philosophy, history, geograpgy, literature, etc.) and from various modern languages (French, German, Italian, Russian, etc.). A decisive role in the modernization of literary Romanian was played by the representatives of the so-called "Școala Ardeleană" [The School from Transilvania], who put together a series of normative works (grammars, orthography textbooks or lexicons), translated scientific and legal-administrative treatises, as well as many literary works, accounting thus for the main requirements regarding the standardization and modernization of literary Romanian (Gheție, 1982, p. 75). The high number of Romanian translations dating back to the same period were insufficiently investigated from the point of view of translation strategies. Within this context, we aim to analyse the way in which proper names from several German texts were formally adapted (graphically, phonetically and morphologically) to Romanian. The cases in point are three historical texts, briefly presented as follows:

a) Descoperirea Américii. O carte foarte folositoare (= Cam.rom.), published in 1816 in Buda, edited by Nicola Nicolau, is the Romanian translation of the first volume of the work Kolumbus oder die Entdekkung von Westindien. Ein angenehmes und nützliches Lesebuch für Kinder und junge Leute by Joachim Heinrich Campe; the work presents the discovery of America, told by a father to his

\footnotetext{
${ }^{\dagger}$ Acknowledgment: This work was supported by a grant awarded by the Romanian National Authority for Scientific Research and Innovation, CNCS-UEFISCDI, Proper Names in the Romanian Pre-modern Writing (1780-1830): Translation Practices, project number PN-II-RU-TE-2014-4-1108.

*Email addresses: anamaria.gansac@gmail.com (AMG),madandronic@gmail.com (MU).
} 
children, in the form of dialogues; after comparing the German editions, we considered the reference text to be the edition published in 1782 in Tübingen $(=\text { Cam.germ. })^{1}$;

b) The history textbook Élémens d'histoire générale by Abbot Claude-François-Xavier Millot, published starting from 1772 in Paris (in two volumes), was translated into Romanian by Ioan MolnarPiuariu (1749-1815) and published in 1800 in Buda, under the title Istoria universală (=Mil.rom.); its main source was the German version of the work Universalhistorie alter mittler und neuer Zeiten, dating back to 1794 (= Mil.germ.), and attributed to Wilhelm Ernst Christiani ${ }^{2}$;

c) The work Alexander I, Kaiservon Russland. Ein Regierungs-und Karaktergemälde (Berlin, 1814) by Johann Daniel Friedrich Rumpf (= Rum.germ.) was published, just like other laudatory portraits of Tzar Alexander I of Russia in order to counteract the Napoleonic myth and raise the prestige of the French emperor's adversary; the translation into Romanian, Arătarea stăpininirei şi a caracterului lui Alexandru I, impăratul a toată Rossia (= Rum.rom.), was published in 1815 in Buda, without mentioning the translator's name ${ }^{3}$.

The texts mentioned above contain various types of toponyms: hydronyms (names of oceans, seas, lakes, rivers, streams), horonyms (names of continents, countries, administrative divisions, regions, provinces), oikonyms (names of habitats: cities, fortresses), oronyms (names of mountains and hills) and nesonyms (names of islands). Starting from the translation strategies adopted by translators, our aim is to analyse the way in which the toponyms from the mentioned texts were adapted to the formal system of Romanian.

\section{Difficulties in the formal adaptation of proper names in pre-modern Romanian}

Although the adaptation of proper names in Old and pre-Modern Romanian is insufficiently studied, it is commonly known that the process is characterized (just like the entire Romanian writing of the time) by the lack of generally valid norms ${ }^{4}$. In the absence of any norms ${ }^{5}$, the oscillations in the adaptation of proper names are determined by the facts described below.

a) The use of different alphabets

The source-texts are written in Latin alphabet. At the time, the Romanian language was written mostly in Cyrillic alphabet. We are thus dealing with two different graphic systems, which means: a different number of graphemes, specific diacritics (with or without phonetic value), the existence of graphemes with multiple phonetic values or, on the contrary, graphemes or grapheme clusters that note the same phonetic sequence. The confrontation of these two graphic systems implies difficulties in choosing a way of transposing proper names into Romanian.

b) Different orthographic systems

The languages involved in the translation of the above-mentioned texts have spellings that are based on different principles: the German orthography exhibits etymological tendencies, while the Romanian-Cyrillic spelling is phonetic.

As far as the principle underlying the Romanian spelling is concerned, specialists in the field have divergent opinions. The "classic" opinion is that the Romanian-Cyrillic spelling is phonetic: "Aplicarea alfabetului chirilic în scrierea limbii române, încă înainte de secolul al XVI-lea și pînă la jumătatea secolului trecut, nu s-a efectuat în virtutea unor norme ortografice fixate în scris, care să fi fost obligatorii pentru toți mînuitorii condeiului, așa încît aceștia—scriind—se lăsau conduși

\footnotetext{
${ }^{1}$ The translator is not mentioned.

${ }^{2}$ On the source of this translation, see Grămadă (1960, p. 166), Ursu (2002) and Minuț \& Lihaciu (2014).

${ }^{3}$ As regards this translation, see Cernovodeanu (1974).

${ }^{4}$ We use the terms $t$ ra n sposition, $t$ ran sfer and $t$ ra n slation in their broad sense, i.e. rendering one linguistic sign from one language into another; we will specify each time the translation strategies met in the studied texts ( $\mathrm{t} r$ a $\mathrm{n}$ sl i t e r a t i o n, transcription, etc.).

${ }^{5}$ The lack of clear norms in rendering foreign proper names into Romanian is characteristic to the modern era; see Ștefănescu (1957), Bârsan (1961), Bolocan (1961), Theban (1965). As far as the transposition of proper names from classical languages, systems are proposed by Creția (1958) and Costa (1958); as regards this operation, the use is still not unitary.
} 
de fonetismul pe care îl deprinseseră în vorbirea limbii; aşa se explică şi faptul [...] că s-a aplicat ortografia fonetică (s.a.) de la începuturile scrisului în limba română" [The application of the Cyrillic alphabet in the Romanian writing, even before the $16^{\text {th }}$ century, and up to the middle of the last century, was not carried out based on written orthographic norms, mandatory for all the scriveners; this means that, in their writing, they would be led by the phonetics they had learned through the spoken language; this also explains the fact that phonetic spelling has been used since the beginnings of Romanian writing] (Strungaru, 1976, p. 197). In this sense, Stan (2012, p. 7) finds it symptomatic that, in the Lexicon of Buda (1825), Cyrillic notations were meant to indicate the utterance; therefore, those in Latin alphabet represented the etymological option in Ardeal, while those in Cyrillic characters pointed to the phonology of the word. On the contrary, Boerescu (2014, p. 88) argues that the traditional Romanian Cyrillic writing "este, de la începuturi și pînă aproape de 1830 [...], o scriere bazată exclusiv pe tradiția slavonă și pe etimologismul cultural grec, cu insuficiente adaptări la fonetica limbii române" [was, from the beginning and until 1830, a type of writing based exclusively on the Slavonic tradition and the Greek cultural etymology, with insufficient adaptations to the phonetics of Romanian]. This opinion differs widely from that of Strungaru (1976), expressed above; the impression of "phonetic" writing would come from the regularization after 1750. Supporting the idea that the Romanian-Cyrillic spelling was traditional and etymologic, Boerescu (2014, p. 88) relies on the research carried out by Gheție \& Mareș (1985, p. 153-164), which shows that the words are used in the first Romanian texts with the values they had in the medio-Bulgarian writing. However, the authors distinguish between religious writings with this feature and the documents of the epoch, characterized by a simplifying spelling and a tendency to leave out conventional uses (Gheție \& Mareș, 1985, p. 161); this leads thus to a rather phonetic spelling (although the traditional component is still present). Equally, this was even more valid two centuries later, especially in secular texts. In our opinion, the author exaggerates the etymological character: it can only be correlated with the words originating from Slavonic and Greek, not to inherited or Slavic words, whose writing is phonetic, to which a strong traditional component is added. When a word is written in Cyrillic alphabet, the scribe does not intend to obtain a form that is very close to the etymon, but tries to reproduce the pronunciation, within the limits of the graphic system he uses, with its traditional components. The idea regarding the existence of a fundamental difference between writing before and after 1750 is refuted by the texts used as a case in point for this study; we notice words with multiple values, words and diacritics with no phonetic value, or graphic doublets. Certainly, from the first writings in Romanian dating back to the $16^{\text {th }}$ century, and up to mid $-18^{\text {th }}$ century, orthography has evolved towards the simplification of some rules, especially as regards the graphemes specialization; however, as our texts show, this development is not significant. We also agree with the idea that the double writing from the Lexicon of Buda (1825) points out to the different principles that the two orthographies of the time (Cyrillic and Latin) are relied on.

c) Different phonetic systems

Each language has phonemes which do not exist in other languages; this means they need to be approximated in the target-language. In the German sources, such phonemes are, for example, the rounded closed front vowel /y/ (represented graphically in German as $\ddot{u}$ ) and the rounded open front vowel /œ/ (represented graphically in German as $\ddot{o}$ or $o e$ ).

d) The diversity of proper names

The translations dating back to this period often refer to realities that were unusual for the Romanian culture of the time (exotic spaces): Cam.rom. talks about South and North America; Mil.rom. is a universal history; Rum.rom. presents aspects of the history, geography and politics of the Russian Empire. Some of the realities contained in these works and their names were, of course, known to the translator and even to the intended target readership; others were unknown, and therefore the translator cannot relate them to any known system. In most cases, the realities a specific work refers to are outside its linguistic sphere. Consequently, instead of rendering the source-language 
spelling or pronunciation (for which the name is an exonym), the translator might try to render the pronunciation he understands or assumes in the language corresponding to the universe referred to by the text.

e) The existence of traditional pronunciation models (for the well-known proper names)

This limits the possibility of translator's innovations. It is what Garde (1974, p. 4) notices when he speaks about the transcription of French proper names into contemporary Russian: there is a conflict between proper names lacking notoriety, unknown, which can be subjected to a transcription according to unitary principles, and the ones that are well-known, which already have a graphic and/or phonetic tradition in the target-language and must be kept accordingly.

\section{Graphic and phonetic adaptation. Translation strategies}

\subsection{The loan}

The loan consists of taking the proper name with the graphic and morphological form as such from the source-language. Ballard (2011, p. 26) calls this strategy report, and defines it as "transferul integral al numelui propriu din textul-sursă în textul-țintă” [the complete transfer of a proper name from the sourcetext into the target-text], "gradul zero al traducerii semnificantului" [ground zero of the translation of the signifier], although he further argues that both transliteration and transcription are report strategies (Ballard, 2011, p. 42).

In the case of Cam.rom., there is sometimes an interesting case of "monolingual bigraphism"; the phrase belongs to Boerescu (2014, p. 87), who uses it to define the coexistence of both the Cyrillic and Latin alphabets in Romanian during 1780-1880. In this paper, the phrase is used to define the situations (specific to this text only) in which the author, transcribing a toponym from the German text, reproduces it in both alphabets. There are three types of situations. In one of them, the original toponyms are reproduced only in Latin alphabet (1):

(1) Dominika (Cam.germ., 132) - Dominica (Cam.rom., 78),

Marigalante (Cam.germ., 133) - Maria galante (Cam.rom., 78),

Guadalupe (Cam.germ., 133) - Kuadelupe (Cam.rom., 78),

Antigua (Cam.germ., 133) - Antiqua (Cam.rom., 78),

Portoriko (Cam.germ., 133) - Porto Rico (Cam.rom., 78),

die Insel St. Martin (Cam.germ., 133) - St. Martin (Cam.rom., 78).

The original name is taken as such only once (St. Martin - St. Martin). In all the other examples, the form of the name, although translated into Romanian using the Latin alphabet just like the source-text, is modified as follows: by replacing $k$ with $c$ (Porto Rico, Dominica; see also the different segmentation in the case of the oikonym Porto Rico ${ }^{6}$ ); by replacing the sound consonant $g$ with its silent correspondent (Antiqua, Kuadelupe; in the case of Antiqua, it is very likely that the closeness to the Latin form played an important role), although the original pronunciation does not justify this replacement (cf. MÜLLERS, s.v.); Mari is ranked in the category of feminine proper names ending in -a (cf. Fr. Marie-Galante, Sp. Marigalante). Therefore, although the source- and target-text use the same alphabet, the transfer strategies are, in most cases, transcription, phonetic adaptation and morphological adaptation.

The proper names borrowed from the source-text in Latin alphabet are doubled by their Cyrillic form (2):

(2) Portosanto (Cam.germ., 11) - Порто Gánтo, Porto Santo (Cam.rom., 9),

Madeira (Cam.germ., 11) - MaAépa, Madeira (Cam.rom., 9), Quibio (Cam.germ., 244) - Kwibio, Кви́вї (Cam.rom., 162),

\footnotetext{
${ }^{6}$ The scholar was probably familiar with the toponyms in their Spanish form.
} 
St. Domingo (Cam.germ., 256) - St. Domingo, Gánт Аоми́мro (Cam.rom., 172, 185, 187), die Stadt Nombre de Dios (Cam.germ., 237) - cetatea Nombre de Dios ${ }^{7}$, Nomepe ae Aïo (Cam. rom., 158) ["the city of Nombre de Dios"].

This time, the Latin alphabet form is taken by approximate imitation, with the exception of Kwibio, cf. Germ. Quibio, where the transfer strategy is transcription (see again the different segmentation for Porto Santo). The Cyrillic form transliterates here the Latin one from the Romanian text.

Group (3) presents several types of situations:

(3) das Vorgebirge der guten Hoffnung (Cam.germ., 12) - munților de Bona Speranza, в8ेмей N'ъA K'\%аe (Cam.rom., 9) ["to the mountains of Bona Speranza, of the good hope"], den Namen Trinidad (Dreieinigkeit) (Cam.germ., 179) - Trinidat (adecă Трои́цъ) (Cam.rom., 114) ["Trinidat (namely, Trinity)"],

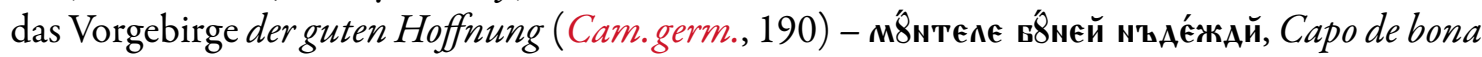
Speranza (Cam.rom., 123),

Gracias a Dios, oder Gott sei Dank (Cam.germ.,230) - numi acest munte: Gratias a Dios, care va

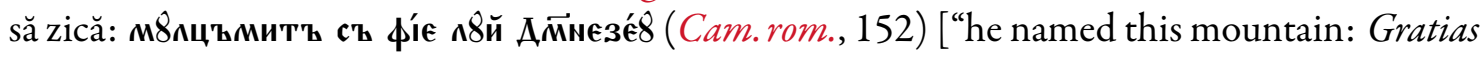
a Dio, which is: Thank God"],

Porto bello (Cam.germ., 237) - Porto bello, adecă Химán \$p8мóc (Cam.rom., 158) [“Porto bello, namely Beautiful harbour"].

Proper names written in Latin alphabet are either loans from the original (Porto bello), substitutions (munților de Bona Speranza, Capo de bona Speranza), or transcriptions (Trinidat, cf. Germ. Trinidad, according to the German rule where final $d$ is voiceless); to this is added the Latinization of Gracias a Dios, i.e. Gratias a Dios. The Cyrillic writing is used when the toponym is doubled through translation: „Trinidat (namely Трои́цъ)”, „Gratias a Dios, which is: м8пцъмитъ съ фієє п8й Аімнєзе́8”, „Porto bello, namely Хима́n фр8вмóc".

\subsection{Transliteration}

Transliteration is the strategy by which the target-language writing is faithfully reproduced in the sourcelanguage, so that each sign in the target-text alphabet corresponds to one in the source-text alphabet (see Elman, 1986, p. 29; Grass, 2002, p. 662-663). Obviously, the strong focus on the graphic level will lead to a phonetic imbalance.

During the pre-modern period of Romanian, the use of transliteration as a strategy of transposing proper names from a foreign language into Romanian posed problems related to the general difficulties of using the Cyrillic alphabet. These originated in the fact that the alphabet was not compatible in all aspects with the phonetic structure of Romanian, which implies the presence of several letters with multiple values $(\mathbf{h}, \mathbf{k}, \mathbf{v}, \mathbf{k}, \mathbf{A})$, the fact that the same phoneme can be denoted by several letters (with the same phonetic

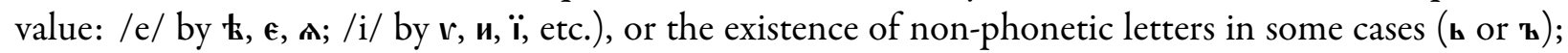
problems are amplified by the lack of general rules for the use of the Cyrillic alphabet, which allowed each translator to innovate within the limits of Romanian graphic system.

One of the problems that occur in the case of transliteration from Latin into Cyrillic points to the difference in number of graphemes between the Cyrillic and the Latin alphabets. This means that, in some cases, the translator may choose from the signs that the Cyrillic alphabet offers. In this case, the very definition of this strategy of translation is questioned, since the same Latin sign can be-and it actually is-transcribed in several ways in the Cyrillic alphabet. Transliteration as such can only concern those cases of 1:1 equation, in one sense or the other, which are scarcely represented; in the other cases, we can talk about approximate transliteration or variants of transliteration. Analysing the Latin

\footnotetext{
${ }^{7}$ Written Dioe, probably a typographic error.
} 
Ana-Maria Gînsac, Mădălina Ungureanu

alphabet transcription and the transliteration of contemporary Russian proper names ${ }^{8}$, Sakhno (2006, p. 711) shows that transliteration is not always accurate (besides the fact that it is often combined with the transcription of the same name) and delimits the exact transliteration (Cyrillic signs without any direct equivalent in Latin alphabet are often rendered with the help of diacritics, for example, Gorbačëv) from the approximate transliteration (the diacritics are omitted, as in Gorbacev). Moreover, Bagajewa (1993, p. 350-351) notices the inconsistency of transliteration and the difficulties it poses, including here even the exact loan of proper names between languages using the same alphabet (e.g. phonetic problems posed by the existence of different spelling rules) ${ }^{9}$. Therefore, if this problem characterizes the situation in the current language, it is even more so a characteristic of pre-modern Romanian. Consequently, we also included in this category (transliteration) the situations of partial overlapping (graphic differences occur), as long as they did not affect the pronunciation.

Another problem in identifying the cases of transliteration is that of accent. In the source-texts, the accent is not marked (4); the onomastic dictionaries of the epoch did not always mark it (the proper names of people are very poorly represented in lexicographic works), so it is difficult to determine whether accent in the Romanian text corresponds to that in the source-text. The examples below (4) indicate situations where transliteration is used for adapting the toponyms from the source-texts:

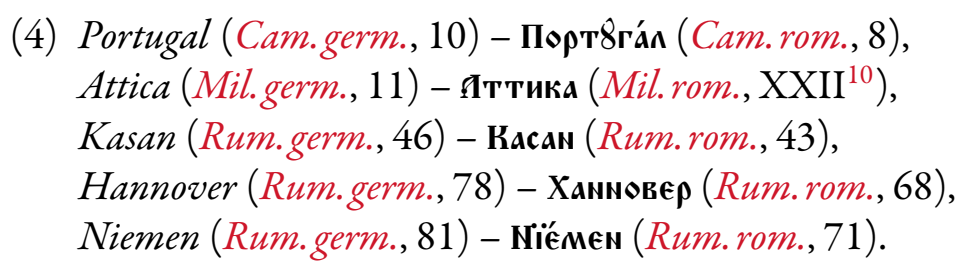

In the last three examples, the choice of transliteration involves different pronunciations in the targetlanguage compared to the source-text: $s$ when placed between two vowels $=/ \mathrm{z} /$ (Kasan); final $-e r=/ \mathrm{a} /$ (Hannover); the graphic group -ie- (Niemen) is pronounced in German as a long $i$.

As regards the capital letters, it should be pointed out that, at that time, it was used both in the case of proper names, and of other words. Each text has its own features, as follows:

a) in Cam.rom., capital letters mark proper names, rarely other words (e.g., Căpetenia, Cam.rom., 8; Gheografia, 10; Observații, 13; Crocodilu, 47);

b) in Mil.rom., the capitals consistently mark proper names, but they are more often used at the beginning of other types of words than in the other texts (and, as it seems, randomly);

c) in Rum.rom., proper names are written in capital letters; in addition to these, capital letters are used with certain common names that designate public functions or that are neologisms (e.g., Sisteme, Rum.rom., 11).

\subsection{Transcription}

In the case of transcription, attention focuses not on the graphic form, but on the phonetic value of proper names. As a general principle, it should render the pronunciation of the original language as faithfully as possible. The principle of fidelity to the pronunciation of the source-language still constitutes the norm in the case of proper names taken from languages with different alphabets, although it is still a desideratum; see, in this respect, Sakhno (2006), who discusses the differences resulting from the transliteration of Russian proper names and the way in which they "betray" the principle of fidelity to pronunciation.

In our texts, the phonetic transcription of proper names can follow the source-language model (the translator reproduces the name as it occurs in the source-language) or a pre-existing model (the transcription in Romanian does not follow the pronunciation of the source-text, but it is consistent with a

\footnotetext{
${ }^{8}$ The internet is the source of the corpus used.

${ }^{9}$ See also Lehrer's conclusions (1993, p. 400) regarding the impossibility to create a translation algorithm for proper names.

${ }^{10}$ The table of contents of Mil. rom. is placed before the text and its pages are marked in Roman letters.
} 
pre-existing pattern of letters/clusters of letters pronunciation). Transcription is often combined with transliteration and phonetic adaptation.

The groups below contain transcription examples, with the following particularities: ae/ $\ddot{a}=\mathbf{\epsilon}(5 \mathrm{a}) ; z$ $/ \mathrm{ts} /=\mathbf{u}(5 \mathrm{~b}) ; c+e, i=\mathbf{u}(5 \mathrm{c}) ; C h=\mathbf{X}(5 \mathrm{~d}) ; P h=\$(5 \mathrm{e})$; the marking of the voiceless pronunciation of the final consonant in German $(d=t)$ in group $(5 \mathrm{f})$ :

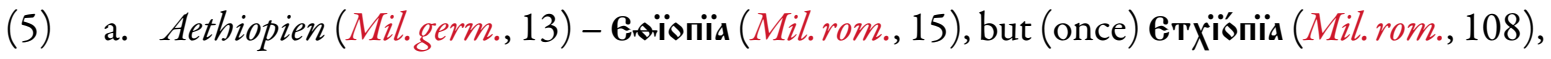
Aegos Potamos (Mil.germ., 265) - Gróc Пота́moc (Mil.rom., 387),

b. Barzelona (Cam.germ., 125) - Барцеко́ма (Cam.rom., 73),

Klazomenä (Mil.germ., 282) - Кпацоме́ма (Mil.rom., 412),

Zanguebar (Cam.germ., 190) - Ценгвева́р (Cam.rom., 124),

Danzig (Rum.germ., 82) - Аа́мциг (Rum.rom., 73),

c. Lacedämons (Mil.germ., 9) - Пацеаємón8п8й (Mil.rom., XIX),

Decelia (Mil.germ., 259) - Аєце́n̈̈а (Mil.rom., 376),

Sicilien (Mil.germ., 258) - Сици́nїа (Mil.rom., 374),

Phocis (Mil.germ., 247) - Фóцис (Mil.rom., 358),

Mycenä (Mil.germ., 152) - Мице́ме (Mil.rom., 204),

d. China (Mil.germ., 4) - Хи́мa (Mil.rom., XI), but Ки́мa (Rum.rom., 73),

Colchis (Mil.germ., 150) - Kónxúc (Mil.rom., 202),

e. Pheres (Mil.germ., 291) - Ф'́́pec (Mil.rom., 427),

f. Trinidad (Cam.germ., 181) - Тримида́т (Cam.rom., 115),

Madrid (Cam.germ., 22) - Мадри́т (Cam.rom., 17),

g. Dominika (Cam.germ., 132) - Dominica (Cam.rom., 78),

Guadalupe (Cam.germ., 133) - Kuadelupe (Cam.rom., 78),

Antigua (Cam.germ., 133) - Antiqua (Cam.rom., 78),

Quibio (Cam.germ., 244) - „Kwibio, Кви́вї̈” (Cam.rom., 162).

The adaptation of foreign toponyms is characterized by some degree of stability, which can be accounted for by the fact that they are generally well known proper names. However, we often notice hesitations, the mixture of strategies and linguistic patterns, frequently in the case of the same toponym (e.g., Xи́мa vs Ки́ма, under the influence of different linguistic patterns).

The group $g u$ (5g), which occurs in South American/Spanish toponyms, is transposed into Romanian bу кв: Guadalupe - Kuadelupe, Antigua - Antiqua; cf. anthroponyms Guakanahari (Cam.germ., 155) Квакамаха́ри (Cam.rom., 95), Aguado (Cam.germ., 167) - Яква́Aจ (Cam.rom., 104). However, in ANLEITUNG, s.v., the Spanish pronunciation is recommended in these cases (e.g., Guadalquivir /guadalkiwir/; Quito /kito/; but Quarnero /kwarnáro/ - a bay in the Adriatic Sea, cf. Croat. Kvarner).

In Cam.rom., the transcription (or transliteration) in Cyrillic letters is sometimes doubled by the replication of the name in Latin alphabet (see above, $\$ 3.1$ ); this is not a transliteration [see (5g)], as would be expected, but a bizarre transcription of the original pronunciation $(q u=k w$; initially voiceless $G$ into $k ; g u=k u)$.

\subsection{Transcription by phonetic approximation}

The need for phonetic approximation is determined by incompatibilities between the phonetic systems of the languages that come into contact. Faced with a non-existent phoneme in his own language, the translator approximates it. We will now refer to the phonetic changes that sometimes occur in the transcription process.

The phonetic approximations in the texts with a German source (6) refer to some vowels that the Romanian language system does not have: /y/ (the close front rounded vowel, noted as $\ddot{u}$ or $y$ ) and /⿷/ (mid-open front rounded vowel, noted $o e$ or $\ddot{\theta}$ ): 
(6) Südamerika (Cam.germ., 197) - Зи́А-Яме́рика (Cam.rom., 128),

Brünn (Rum.germ., 80) - Брим (Rum.rom., 70),

Lübeck (Rum.germ., 82) - Пюве́к (Rum.rom., 72),

Hayti (Cam.germ., 88) - Xа8ти́́ (Cam.rom., 49),

Böotien (Mil.germ., 281) - Бєóціï (Mil.rom., 411),

Pötidäa (Mil.germ., 246) - Поти́́аєа (Mil.rom., 356),

den See Moeris (Mil.germ., 12) - М'́ṕc (Mil.rom., 13).

In reproducing these vowels, the translators oscillate between $\mathbf{и}, \mathbf{s}$ and 8 for $\ddot{u}$ and $y$ (thus, between vowels

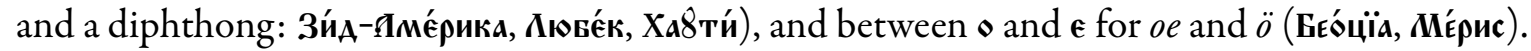

\subsection{A particular case of adaptation: phonetic substitution}

We do not refer here to substitution as a strategy of translating proper names by replacing them with an already existing Romanian proper name, for example: Impărăția Turcească for Turcia, Crăia Franţuzului for Franța, Țara Ungurească/Pămîntul Unguresc for Ungaria ${ }^{11}$. We rather take into account what Ballard (2011, p. 42-43) calls "phonetic assimilation", more precisely, a special case that derives from the particular situation characterizing the pre-modern Romanian culture at that particular time. The terminology of Ballard seems here inadequate, as it may create confusion if we relate it to the phenomenon of phonetic assimilation. Ballard also relies on the relationship between French and English; in his view, phonetic assimilation means distinct phonetic variants (for French, English, etc.) of the same proper name. Vaxelaire (2006, p. 720) calls this strategy "adaptation".

The situation in the texts discussed here is somehow more complicated, because it leads to the emergence of a third idiom in the equation source-language - target-language. The Romanian culture is characterized, both in the old age and at the beginning of the pre-modern period, by the use of a language of culture other than Romanian; for the old age, this was Slavonic; in the $18^{\text {th }}$ century, with the Phanariot Age, the Slavonic was replaced by Greek to such an extent that the Greek actually became a tool by means of which culture was circulated within the Romanian Principalities, just as in Transylvania the language of culture was mainly Latin. Under these circumstances, the translator often chooses not to reproduce the pronunciation of the original proper name by transcription, but, especially when it is an exonym in relation to the source-language, replaces it with a familiar variant (one that is accepted, as phoneticism shows, through Greek or Latin), or recovers the pronunciation of proper name from the language corresponding to the reference universe of the text. In another subtype, when transcribing an exotic toponym, for which, on grounds of novelty, there is no equivalent in one of his reference linguistic systems (Romanian, Greek, Latin), the translator does not reproduce the pronunciation from the source-language, but transcribes it according to the pronunciation of the form existing in the reference language of the text.

Therefore, by phonetic substitution, we mean replacing the pronunciation specific to the source-language with a pronunciation that was previously used by the translator, or with the pronunciation specific to the reference universe of the text. Group (7) contains examples of substitutions of well-known toponyms from the German text by their equivalents that already existed in Romanian; the model is the German medieval pronunciation of Latin $(c i=t, i, c e=t, e)$ :

(7) Cilicie (Mil.fr., 7) - Цики́цїа (Mil.rom., XXI),

Celé-Syrie (Mil.fr., 6) - Целєси́рї̈ (Mil.rom., XXI), Damascène (Mil.fr., 23) - Дамасце́ne (Mil.rom., XXI).

In the case of Livland (Rum.germ., 51) - Ки́фпама (Rum.rom., 48), the translator considered the Russian model in transcription (cf. Rus. Аифляндuя). The existence of several pronunciation patterns is obvious below (8):

\footnotetext{
${ }^{11}$ Cf. „desemnare distinctă” [“distinct designation”] (Ballard, 2011, p. 54-55) or „dénomination multiple” (Vaxelaire, 2006, p. 720).
} 
(8) Cypern (Mil.germ., 282) - Ки́пр8 or Ци́пр8п (Mil.rom., 412), Scyros (Mil.germ., 282) - Gци́poc or Gки́рос (Mil.rom., 412),

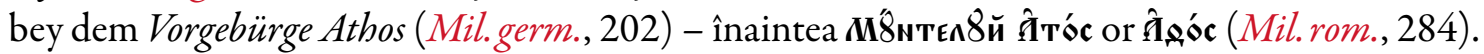

The translator explicitly states that a given toponym may have different pronunciations. Differences arise either from the specific linguistic patterns, or, as in the case of Athos, from the use of different transfer strategies (transcription or transliteration).

\section{Morphological adaptation}

Some foreign toponyms entered the Romanian language through several languages (Greek, Italian, French, German etc.), receiving thus various forms. Others were replaced by their Romanian (formal or denominative) correspondents, established by $\operatorname{tradition}^{12}$ (9), as is the case in the translations under study:

(9) Aegypten (Cam.germ., 13) - Eghipet (Cam.rom., 10), von Genua (Cam.germ., 20) - Ghénovii (Cam.rom., 15), Venedig (Cam.germ., 15) - Venéția (Cam.rom., 11), Frankreich (Cam.germ., 152) - Fránța (Cam.rom., 92);

Deutschland (Mil.germ., 115) - Ghermánia (Mil.rom., 157), Theben (Mil.germ., 279) - Thévi13 (Mil.rom., 408);

Russland (Rum.germ., 6) - Rósia (Rum.rom.,7) or Țeara Rusască (Rum.rom., 3), England (Rum. germ., 6) - Ánglia (Rum.rom., 7), Moskau (Rum.germ., 28) - Móscva ${ }^{14}$ (Rum.rom., 26), Deutschland (Rum.germ., 81) - Țara Nemțească (Rum.rom.,71), Frankreich (Rum.germ., 84) - Fránția (Rum.rom., 74), etc.

In the absence of translated proper names corpora prior to the period we are studying, in some cases it is difficult to determine whether a certain form was established by the translator on the basis of the translated source or it was imposed by tradition.

\subsection{Classification into the grammatical category of gender}

Based on a proper names corpus made up of a few texts dating back to the second half of the $19^{\text {th }}$ century, Ichim-Tomescu (1978) discusses the possibility of adapting foreign oikonyms to Romanian. According to the typology she proposes (p. 238), the toponymic endings specific to the Romanian gender series are: a) $-a$, with the variants $-(i) a$ and $-(e) a$, for the feminine; b) $-u$ plus consonant, for the masculine; $c)$ the endings $-e$ and $-i$, of foreign origin, as well as the ending $-o$ (which is uncommon for the Romanian toponymic system) are not specific in establishing grammatical gender in Romanian, and may raise problems regarding their adaptation.

The integration of the foreign toponyms from the above texts within the Romanian gender classes is determined by linguistic factors (for example, the toponymic endings specific to the Romanian language and those specific to the language from which translation is carried out, the degree of familiarity with the language of the translated text), as well as extralinguistic factors (such as the translator's cultural training, the prevalent cultural model). Depending on these factors, translators adopt a certain strategy for transposing the endings from the translated texts into Romanian (e.g. substitution, transliteration, or adaptation of the ending).

a) As far as horonyms are concerned, the ending -en is replaced with -ia, e.g.: Brasilien - Brazilia; Spanien - Spánia; Italien - Itália; Indien (Mil.germ., 13) - India (Mil.rom., 15); Persien (Mil. germ., 17) - Persia (Mil.rom., 20); Assyrien, Syrien (Mil.germ., 74) - Assiria, Siria (Mil.rom., 103);

\footnotetext{
${ }^{12}$ Cf. "numirile tradiționale, cu formă românească (Londra, Viena etc.)” (Ștefănescu, 1957, p. 76).

${ }^{13}$ Cf. Gr. $\Theta \tilde{\eta} \beta \alpha \iota$.

${ }^{14}$ Or from Moskwa (Rum.germ., 86), which appears in other contexts within the German source-text.
} 
Sardinien, Andalusien (Mil.germ., 79) - Sardinia, Andaluzia (Mil.rom., 108); Medien (Mil.germ., 97) - Média (Mil.rom., 129); Gallien (Mil.germ., 124) - Gállia (Mil.rom., 171); Ionien (Mil.germ., 165) - Ionia (Mil.rom., 224). The preservation of geminates points to the fact that the translator did not resort to an already adapted form, but he attached the Romanian ending - ia to the radical of the original toponym. Furthermore, the ending $-i a$ was often added to the German pronunciation of proper names, for example: Sicilien (Mil.germ., 12) - Sițilia (Mil.rom., 14), Bäotien (Mil.germ., 219) - Beótia (Mil.rom., 313), Macedonien (Mil.germ., 245) - Mațedónia (Mil.rom., 354).

b) The oikonyms and the horonyms ending in $-a$ are usually preserved with this ending (specific to the Romanian toponymic system), for example: Barzelona (Cam.germ., 125) - Barțelóna (Cam.rom., 73), Madeira (Cam.germ., 16) - Madeira (Cam.rom., 12), Jamaika (Cam.germ., 145) - Iamaica (Cam.rom., 87), Sparta (Mil.germ., 10) - Spárta (Mil.rom., XXI). The toponym Mycenä $\ddot{1}^{15}$ (Mil. germ., 152), rendered in German pronunciation (Mițéne, Mil.rom., 204), is added the ending -e, non-specific to the Romanian toponymic system.

c) Some toponyms ending in a consonant are added the feminine ending-a, for example: Athen (Mil. germ., 8) - Athina (Mil.rom., XVII), Syracus (Mil.germ., 14) - Siracúsa (Mil.rom., XXVIII), Rom (Mil.germ., 25) - Róma (Mil.rom., 32), etc.; others are not: Salamin (Mil.germ., 12) - Salamín (Mil.rom., XXIV).

d) In Cam.rom., the endings $-e,-i$ and $-o$ are usually preserved (10). The original consonant endings are also retained in Romanian (11):

(10) Oronoko (Cam.germ., 182) - Oranóco (Cam.rom., 116), cf. Oranócului (114), Tejostrom (Cam.germ., 121) - rîul Teio (Cam.rom., 70),

Mexico (Cam.germ., 227) - México (Cam.rom., 150),

Charthago (Mil.germ., 367) - Cartágo (Mil.rom., 253),

Kowno (Rum.germ., 57) - Cóvno (Rum.rom., 54),

Borodino (Rum.germ., 85) - Borodino (Rum.rom., 76),

Guanahani (Cam.germ., 76) - Cvanábani (Cam.rom., 41),

Hayti (Cam.germ., 88) - Hauti (Cam.rom., 49),

Guadalupe (Cam.germ., 133) - Kuadelupe ${ }^{16}$ (Cam.rom., 78),

Ninive (Mil.germ., 63) - Ninive (Mil.rom., 84),

Mycale (Mil.germ., 221) - Micále (Mil.rom., 312),

(11) zu Lissabon (Cam.germ., 14) - la Lisavón (Cam.rom., 11),

Madrit (Cam.germ., 22) - Madrit (Cam.rom., 17).

In other texts, the German ending $-e$ is sometimes replaced by the Romanian one $(-a)$; see, for example, Mytylene (Mil.germ., 264) - Mitiléna (Mil.rom., 384). Furthermore, the feminine ending

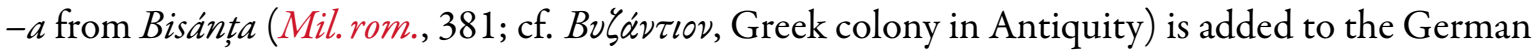
pronunciation of Byzanz (Mil.germ., 262), perhaps due to the need to articulate the toponym following another proper name which is articulated, correlating it at the same time to the gender of the category of objects ("citadel, city") it belongs to: "Helespóntul, Bisánța și alte cetăți le supune puterii Athínii" (Mil.rom., 381), cf. "und brachte der Hellespont, Byzanz, und viele Städte unter die Gewalt Athen" (Mil.germ., 262). The toponym Byzanz also appears with the ending -ia: "Hiós, Cós, Ródus și Bizánția” (Mil.rom., 434), cf. "Chio, Cos, Rhodus und Byzanz" (Mil.germ., 296).

e) Ioan Molnar Piuariu, speaker of Latin, Hungarian and German, preserves in translation the Latin and Greek endings, common in German, for example: Tyrus (Mil.germ., 82) - Tirus (Mil.rom., 112), „Stadt Byblos” (Mil.germ., 82) - „cetatea Biblos” (Mil.rom., 113), Ganges (Mil.germ., 128) Gánghes (Mil.rom., 176), Delphos (Mil.germ., 200) - Délfos (Mil.rom., 149), Chersones (Mil.germ., 206) - Hersonés (Mil.rom., 290), Eleusis (Mil.germ., 159) - Eleúsis (Mil.rom., 214), Artemisium

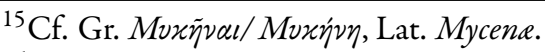

${ }^{16}$ Written in Latin alphabet.
} 
(Mil.germ., 215) - Artemisium (Mil.rom., 307). The toponyms with Latin or Greek ending are rarely substituted with the existing Romanian forms; one example is Damascus (Mil.germ., 74) Damásc (Mil.rom., 103).

\subsubsection{Gender oppositions}

Gender is determined based on both the endings of proper names in the source-text (which often varies) and on the strategy of transposition in Romanian: preservation of the original form, adaptation according to the Romanian toponymic system or the reproduction of pronunciation. The same toponym sometimes acquires different endings (feminine, non-feminine/masculine and nonspecific), thus resulting gender oppositions, illustrated below $(12)^{17}$ :

(12) Cipru

der Insel Cypern (Mil.germ., 235, cf. 73) - ostrovul Chiprul (Mil.rom., 339),

in Cypern (Mil.rom., 297) - în Țipria (Mil.rom., 435),

Cipro (Buf.it., 377) - Chipru (Buf.rom., 22);

Lacedemonia

zu Lacedämon (Mil.germ., 240) - în Laţedemón (Mil.rom., 339),

Lacedämons (Mil.germ., 9) - Lațedemónului (Mil.rom., XIX),

Lacedemone (Buf.it., 375) - Lachedemónie (Buf.rom., 21);

Mexic

Mexico (Cam.germ., 227; Mil.germ., 37) - México (Cam.rom., 150; Mil.rom., 53),

il Golfo del Messico (Buf. it., 434) - colful Mésicu (Buf.rom., 152), Mesic (Buf.rom., 156),

Mexique (Dor.fr., 315) - Mexica (Dor.rom., II, 38v).

The source-texts frequently influence the toponyms ending in Romanian translations; accordingly, different formal gender variants are created, such as: Chiprul (masculine) - Țipria (feminine); Mexico (gender ending non-specific to Romanian) - Mexica (feminine) - Mesic (masculine).

\subsection{Number}

In Mil.rom., the form of the nesonyms reflects the German model (insulă/ostrov [island] + adjectival determiner from the name of the island), for example: "mariannischen Inseln" (Mil.germ., 36) - "ostroavele Marianicești” (Mil.rom., 52), "Kanarischen Inseln” (Cam.germ., 16) - "ostroavile Canaricești”" (Cam.rom., 12), "Azorischen Inseln” (Cam.germ., 18) - "ostroavelor Azoriceşti” (Cam.rom., 14). This denomination practice is sometimes used when the source-text does not contain an adjectival form, for example: "Küsten der Azoren" (Cam.germ., 19) - "țărmurile Azoricești”" (Cam.rom., 14), instead of "țărmurile *Azorelor".

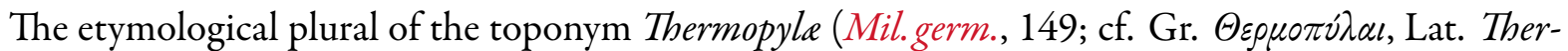
mopyle, "The Hot Gates") is transposed in Romanian as the singular Termopila (Mil.rom., 200). The form Termopile (Mil.rom., 302) renders the German pronunciation of the toponym Thermopylä (Mil.germ., 213).

\subsection{Case inflexion}

The integration of foreign toponyms into the gender and number series of Romanian determines their inflexion (Ichim-Tomescu, 1978, p. 239; Tomescu, 1998, p. 204; Tomescu, 2008). The oblique forms are likely to pose particular problems.

\footnotetext{
${ }^{17}$ For a more comprehensive image on gender oppositions, we also followed the forms of other translations dating back to the same period (Buf.rom. and Dor.rom.).
} 
a) The toponyms included in the series of non-feminine forms (ending in consonants and $-u$ ) as well as those with nonspecific endings (in -o) compose the synthetic oblique forms by attaching the enclytic masculine morpheme -lui, for example: "curgerea Oranócului" (Cam.rom., 115), "craiului Tírului" (Mil.rom., 112), "limanul Piréiului" (Mil.rom., 322). The genitive enclitic morpheme is sometimes added to the Latin ending: "marea Mediterranéumului" (Mil.rom., 109); "Die Festungswerke des Piräeus" (Mil.germ., 266) - "întăririle cetății Pireúsului” (Mil.rom., 388), but "limanul Piréiului" (Mil.rom., 322), translation that does not render the adjective from the source-text: "piräeische Hafen" (Mil.germ., 224).

b) Toponyms ending in $-a$ (or $\left.-i a^{18}\right)$, included in the formal series of feminine proper names, compose oblique cases by means of the enclitic morphemes $-e i$ and $-i i /-i^{19}$, which are in free variation in the studied texts, for example:

Cam.rom.: "aceasta e harta Américei" (Cam.rom., 4), "harta Américii" (Cam.rom., 41), "țărmurile Áfricei” (Cam.rom., 12, cf. 112, 123), "partea de sus a Africii” (Cam.rom., 17, cf. 123), "vistieria Spániei” (Cam.rom., 26), "Craiul Englitérii” (Cam.rom., 92), etc.;

Mil.rom.: Troadei (Mil.rom., 108), "dă războiu Sțitiei sau Schiftii, și Colhisii și Tráții” (Mil.rom., 15), "mai-marele cetăţii Médiei" (Mil.rom., 127), "featii craiului Médii" (Mil.rom., 133), "dătătoriul de leage al Athinii" (Mil.rom., 263), "asupra Siracúzii” (Mil.rom., 368), etc.;

Rum.rom.: "Craiul Ángliei” (Rum.rom., 7), "Craiul Sardiniei” (Rum.rom., 68), "împăratul Aústriei” (Rum.rom., 70), "ceale dinlăuntru ale Rósiei” (Rum.rom., 75, glosă), "se cuvine Róssiei acea laudă” (Rum.rom., 78), etc.; in this text, the genitive-dative morpheme $-e i$ is predominant.

c) In the studied texts, the toponyms ending in -ca or - ga express oblique cases by means of the enclitic morphemes $-e i$ and $-i i$, which vary within the same text or from one text to another; see, for example: "aceasta e harta Américei" (Cam.rom., 4), "harta Américii" (Cam.rom., 41), "țărmurile Áfricei" (Cam.rom., 12, cf. 112, 123), "partea de sus a Africii” (Cam.rom., 17, cf. 123); "părțile Africii" (Mil.rom., 109).

d) Sometimes, the ethnonymic (adjectival) derivatives of the source-text are rendered into Romanian by the corresponding horonym preceded by preposition, with genitive value, for example: "die indianischen Güter" (Cam.germ., 14) - "mărfurile de India" (Cam.rom., 12).

\section{Conclusions}

A characteristic of toponyms translation in the studied texts is o s cillatio n, both as regards the choice of the translation/transposition strategy, and in terms of outcome. The choice of a strategy depends on several aspects: linguistic factors (the incompatibilities between the graphic and phonetic systems, as well as the principles governing the spelling of two languages in contact; the existence, in the case of wellknown proper names, of traditional pronunciation patterns); other factors refer to the translated text (its content and the types of proper names it contains) or the translator's personality (linguistic knowledge and opinions, cultural background). The same toponym (including those very well known) can be transferred in several ways, with multiple results, not just from one text to another, but also within the same text. Sometimes, the translator himself (see Mil.rom.) explicitly indicates that there are several adaptation possibilities into Romanian.

As regards the graph ic and ph o n e tic a d a p t a t i o n, transcription is the most widely used strategy. There are two cases: a) the transcription is directed at reproducing the pronunciation of the proper names in the source-language; b) the translator attempts to reproduce through transcription the pronunciation from a third language (especially in the case of toponyms that are exonyms in relation to the source-

\footnotetext{
${ }^{18}$ As opposed to the translations from texts belonging to the Latin stress model, the texts translated from Greek often preserve cases in which the last syllable is stressed $(-i a)$.

${ }^{19}$ According to Coteanu (1969, p. 119), $-i$ is "a graphic variant of -ii"; see also Diaconescu (1970, p. 208), who argues that $-i$ is the result of the enclitic $-i i$ contraction.
} 
language). Generally, the third language could be one of the languages of culture at the time, one that the translators were familiarized with (in the studied texts, Latin, in its medieval pronunciation), or the language of the reference universe of the text (for example, Russian for Rum.rom., which speaks about the realities of the Russian Empire). Given the lack of overlap between the phonetic systems of languages in translation, translators sometimes operate phonetic approximations, attempting to reproduce the missing phoneme from the Romanian system through one that Romanian possesses.

In terms of morphological adaptation, the inclusion of a given proper name into a specific gender series is influenced by its ending in the source-language (often fluctuating) and by the adopted translation strategy. Thus, the source-language endings can be: a) preserved (by transliteration) or removed (usually resulting a consonant ending); b) substituted with endings that are specific to the denominative system of Romanian (for example, German horonyms ending in -en substituted with Romanian ending in $-i a)$; c) a d a p t e d (usually by transcribing the pronunciation). The multiple adaptation strategies and means (different languages) through which a foreign toponym is rendered into Romanian have led, in some cases, to the creation of gender oppositions; they are then reflected in specific pattern of case and number inflexion. As regards the case inflexion, in the studied texts, the genitive-dative endings $-e i$ and $-i i$ are in free variation.

\section{Bibliography}

\section{A. Sources}

Buf.it. $=$ [Claude Buffier], Geografia universale del P<adre > Buffier, Edizione prima Romana aumentata, corretta e ridotta in miglior forma, con un nuovo Trattato della Sfera e d'una Dissertazione sopra l'origine e progresso della Geografia, dal P<adre> Francesco Jacquier, in Roma, a spese di Venanzio Monaldini, mercante di Libri, 1775.

Buf.rom. = [Claude Buffier], De obște gheográfie pe limba moldovenească, scoasă de pe Geográfie lui Búfiér după orînduiala care acum mai pre urmă s-au aşăzat în Académie de la Parízi, acum întîi tipăită în zilele Prealuminatului și Preaînălţatului Domnului nostru Alexandru Ioan Calimah V<oie > vod, cu blagosloveniia și cu toată cheltuiala Preaosfințitului Mitropolit a toată Moldáviia, Kirío Kir Iácov, întru a Preosfinției sale Tipográfie, s-au tipărit de ierodiacon Gherásim și de Pável Petrov tipografi), în $\mathrm{Sf}<\hat{1}>$ nta Mitropolie în Iaşi, avgust 22, 1795.

Cam.germ. $=$ [Joachim Heinrich Campe], Kolumbus oder die Entdekkung von Westindien. Ein angenehmes und nützliches Lesebuch für Kinder und junge Leute, von J.H. Campe, mit allerhochst gnädigst Kayserl. Privilegio, Tübingen, bey Wilh. Heinr. Schramm und Joh. Friedr. Balz., 1782.

Cam.rom. = [Joachim Heinrich Campe], Descoperirea Américii. O carte foarte folositoare, alcătuită de Ioánn Háinrih Cámpe, acum întîiu de un iubitoriu de neamul românesc pre românie tălmăcită și dată afară la lumină, tomul I, cu 4 figuri, cu toată chieltuiala lui Nicóla Nicoláu din Brașov, dată în tipariu la Buda, Crăiasca Tipografie a Universitatei din Péșta, 1816.

Dor.fr. $=$ [André Guillaume Contant d'Orville], Histoire des différents peuples du monde, contenant les cérémonies religieuses et civiles, lorigine des religions, leurs Sectes \& Superstitions, \& les Mours \& Usages de chaque Nation, dédiée à monseigneur le Duc de Vrilliere, ministre et secrétaire d'état par M. Contant Dorville, tome cinquième, à Paris, chez Herissant le Fils Libraire, 1771.

Dor.rom. $=$ [André Guillaume Contant d'Orville], Istoría Americăi, cuprinzind un perilipsis a aflärii ei, țerimóniile bisericești și politicești [...], acum întîi tălmăcite în dialectul moldovenesc, prin ostineala smeritului Gherasim, arhimandrit Mitropoliei Iaşului, Iași, tomul I (1800), tomul 2 (1795) [în ms. rom. IV-17 BCU-Iași].

Mil.f. $f_{r}=$ [Claude François Xavier Millot], Éléments d'histoire générale, première partie: Histoire ancienne, par M. l'Abbé Millot de l'Académie Françoise, \& des Académies de Lyon \& Nancy, tome premier, Nouvelle édition augumentée, à Paris, Chez Durand neveu, 1790.

Mil.germ. $=$ [Claude François Xavier Millot], Des Herrn Abt $\langle$ Claude $>$ Millot, Mitglieds der Akademie zu Lyon, Universalhistorie alter, mittler und neuer Zeiten, aus dem Französischen, mit den Zusätzen von Wilhelm Ernst Christiani, königlich Dänischen wirklichen Justiz - Rath und ordentlichen Professor der Weltweisheit, Beredtsamkeit und Geschichte, wie auch Bibliothekar der königlichen Universität zu Kiel, Erster Band, Bey Franz Haas Buchhändler, Wien, 1794.

Mil.rom. = [Claude Millot], Istorie universală, ádecă de obște, care cuprinde în sine întîmplările veacurilor vechi, întocmită prin signior Mílot, commembru Académii Frîncești din Lyon, iară acum întîia dată tălmăcită în limba românească, tomul I, în Búda s-au tipărit, în Crăiasca Tipografie Orientalicească a Universitatei Péștii, 1800.

Rum.germ. $=$ [Johann Daniel Friedrich Rumpf], Alexander I, Kaiser von Russland. Ein Regierungs- und Karaktergemälde, von I.D.F. Rumpf, Königl. Preuss. expedir. Secretär bei der Abgaben-Direction in Berlin, bei G. Hayn, mit dem Bildniss des Kaisers, 1814. 
Rum.rom. = [Johann Daniel Friedrich Rumpf], Arătarea stăpininirei și a caracterului lui Alexándru I, împăratul a toată Róssia, întocmită prin I.D.F. Rumpf, Crăiescul Praisesc a Direcției din Berlin Secretar-Expedítor și Mărirei Sale celui pre dreptate și moștenitoriu Craiu al Borúsiei Frídrih Vílhelm III închinată, iară acum întîiu pre Românie prefăcută și tipărită la Buda, în Crăiasca Tipografie a Universitatei Ungáriei, 1815.

\section{B. Reference works}

ANLEITUNG = Anleitung zut richtigen Aussprache geographischer und geschichtlicher Eigennamen, L. Frey'sche Buchhandlung, Ulm, 1863.

Bagajewa, J. (1993). Geographical Names: Problems of Equivalence and Translability, in Lewandowska-Tomaszczuk, B. \& Thelen, M. (eds), Translation and Meaning, vol. II: Proceedings of the Eódź Session of the 1990 Maastricht-Eódź Duo Colloquium on "Translation and Meaning” held in Eódź, Poland, 22-29 September 1990, Rikkhogeschool Maastricht, Maastricht, p. 349-354.

Ballard, M. (2011). Numele proprii in traducere [Nom propre en traduction, Ophrys, Paris, 2001], translation, foreword and notes by Georgiana Lungu-Badea, Editura Universității de Vest, Timișoara.

BERTACCHI = Cosimo Bertacchi, Nuovo dizionario geografico universale, vol. I-II, Unione Tipografico Editrice, Torino, 1904. Bârsan, A. (1961). Considerații asupra scrierii numelor geografice străine, in “Limba română”, vol. 10, no. 5, p. 415-424.

Boerescu, P. (2014). Din istoria scrierii românești, Editura Academiei Române, București.

Bolocan, Gh. (1961). Despre redarea numelor proprii dintr-o limbă în alta, in "Limba română”, vol. 10, no. 6, p. $582-587$.

Boutourlin, P. (1874). Les noms propres étrangers. Leur orthographe et leur prononciation, Seconde Édition, Combe et Vande Weghe imprimeurs, Bruxelles.

Cernovodeanu, P. (1974). Préoccupations en matière d'histoire universelle dans l'historiographie roumaine au XVIIe et XVIIIe siècle, in “Revue Roumaine d'Histoire”, vol. 9, no. 1, p. 73-94.

Coteanu, I. (1969). Morfologia numelui în protoromână (româna comună), Editura Academiei Române, București.

Creția, P. (1958). Numele proprii grecești în românește, in "Limba română", vol. 7, no. 2, p. 54-59.

Costa, T. (1958). Numele proprii latinești în românește, in "Limba română”, vol. 7, no. 4, p. 70-77.

Diaconescu, P. (1970). Structură și evoluție în morfologia substantivului românesc, Editura Academiei Române, București.

Elman, J. (1986). Le problème de la traduction des noms propres, in "Babel”, vol. 32, no. 1, p. 26-30.

Garde, P. (1974). La transcription des noms propres français en russe, Institut d'Études Slaves, Paris.

Gheție, I. (1975). Baza dialectală a românei literare, Editura Academiei Române, București.

Gheție, I. (1982). Introducere în studiul limbii române literare, Editura Științifică și Enciclopedică, București.

Gheție, I. \& Mareș, Al. (1985). Originile scrisului în limba română, Editura Științifică și Pedagogică, București.

Grass, Th. (2002). Quoi! Vous voulez traduire «Goethe»? - Essai sur la traduction des noms propres allemand-français, Peter Lang, Berne.

Grămadă, L. (1960). „Istoria lui Millot” în tălmăcirea lui Ioan Piuariu Molnar, in “Studia Universitatis Babeș-Bolyai. Philologia”, 4/2, p. 161-175.

Ichim-Tomescu, D. (1978). Observații asupra adaptării morfologice a toponimelor străine în limba română, in "Limba română", vol. 27 , no. 3, p. 237-242.

Ivănescu, G. (1980). Istoria limbii române, Editura Junimea, Iași.

Lehrer, A. (1993). Principles and Problems in Translating Proper Names, in Lewandowska-Tomaszczuk, B. \& Thelen, M. (eds), Translation and Meaning, vol. II: Proceedings of the Eódź Session of the 1990 Maastricht-Eódź Duo Colloquium on "Translation and Meaning" held in Eódź, Poland, 22-29 September 1990, Rikkhogeschool Maastricht, Maastricht, p. 395-402.

Minuț, A.-M. \& Lihaciu, I. (2014). Interpolarea ca strategie de traducere a „Istoriei universale adecă de obște, care cuprinde în sine intâmplările veacurilor vechi”, versiune în limba română de Ioan Piuariu Molnar, in Dima, E. \& Corbea-Hoișie, A. (eds), Impulsul Iluminismului în traduceri românești din secolul al XVIII-lea, Editura Universității „Alexandru Ioan Cuza”, Iași, p. 91-136.

MüLlers = August Müllers, Allgemeines Wörterbuch der Aussprache ausländischer Eigennamen, Verlag von E. Haberland, Leipzig, 1903.

Munteanu, Șt. \& Țâra, V.D. (1983). Istoria limbii române literare. Privire generală, Editura Didactică și Pedagogică, București.

Nedelcu, I. (2012). Substantivul, in Chivu, Gh. et al. (eds), Studii de istorie a limbii române. Morfosintaxa limbii literare în secolele al XIX-lea și al XX-lea, Editura Academiei Române, București, p. 37-62.

Piru, Al. (1970). Istoria literaturii române. II: Epoca premodernă, Editura Academiei Române, București.

Sakhno, S. (2006). Nom propre en russe: problèmes de traduction, in "Meta", 51/4, p. 706-718.

Săulescu, Gh. (1833). Grammatică românească sau observații grammaticești asupra limbei românești pentru scoalele normale și ghimnaziale, compusă de Gheorghie Seulescul; partea întîia, Etimologhică, Tipografia Mitropolii, Iașii.

SCHNAKENBURG = J. F. Schnakenburg, Orthographisches Wörterbuch der gesammten alteren und neueren Geographie und der Eigennamen der Personen, Verlag von Johann Ambrosius Barth, Leipzig, 1835.

Stan, C. (2012). Ortografia și ortoepia. Secolul al XIX-lea, in Chivu, Gh. et al. (eds), Studii de istorie a limbii române. Morfosintaxa limbii literare în secolele al XIX-lea și al XX-lea, Editura Academiei Române, București, p. 1-28. 
Strungaru, D. (1976). Pe marginea interpretării normelor ortografice în recentele ediții a două vechi gramatici românești (Evstatievici și Diaconovici), in “Limba română”, vol. 25, no. 2, p. 197-204.

Ștefănescu, C.M. (1957). Transcrierea numirilor geografice străine în text românesc, in "Limba română”, vol. 6, no. 4, p. 76-79. Theban, L. (1965). Din nou despre transliterarea denumirilor geografice străine, in "Limba română”, vol. 14, nr. 1, p. $139-141$.

Tomescu, D. (1998). Gramatica numelor proprii în limba română, Editura ALL, București.

Tomescu, D. (2008). Substantivele proprii, in Valeria Guțu Romalo (coord.), Institutul de lingvistică „Iorgu Iordan - Al. Rosetti", Gramatica limbii române, vol. I: Cuvântul, Editura Academiei Române, București, p. 118-128.

Ursu, N. A. (2002). Contribuții la istoria culturii românești. Studii și note filologice, Editura Cronica, Iași.

Vaxelaire, J.-L. (2006). Pistes pour une nouvelle approche de la traduction automatique des noms propres, in "Meta", 51/4, p. 717738. 